\title{
Effect of Aqueous Extracts of Sticky Willy (Galium aparine L.) on the Growth of Seedlings of Selected Maize Varieties (Zea mays L.)
}

\author{
Joanna PUŁA ${ }^{1}$, Beata BARABASZ-KRASNY², Katarzyna MOŻDŻEŃ ${ }^{3 *}$, \\ Anna SOŁTYS-LELEK ${ }^{4}$, Andrzej LEPIARCZYK ${ }^{1}$
}

\author{
${ }^{1}$ University of Agriculture in Kraków, Faculty of Agriculture and Economics, Department of Agrotechnology and Agricultural Ecology, \\ Al.Mickiewicza 21 St.,31-120Kraków,Poland; rrpula@cyf-kr.edu.pl; a.lepiarczyk@ur.krakow.pl \\ ${ }^{2}$ Pedagogical University, Institute of Biology, Department of Botany, Podchorażych 2 St., 30-084 Kraków, Poland; bbk@up.krakow.pl \\ ${ }^{3}$ Pedagogical University, Institute of Biology, Department of Plant Physiology, Podchorażych 2 St., 30-084 Kraków, \\ Poland; kmozdzen@up.krakow.pl ("*orrespondingauthor) \\ ${ }^{4}$ Ojców National Park, Ojców 9, 32-045 Sutoszowa,Poland; ana_soltys@wp.pl
}

\begin{abstract}
In the environment plants are competing for water, nutrients and light, and other components. Their competition is not only based on shading but on the allelopathic interactions as well. Sticky willy (Galium aparine L.) is a nitrophilous weed growing in thickets, crop fields and on ruderal areas. Its sticky and strongly branching stems are connecting together stalks of grain make it difficult to harvest. G. aparine wraps around plants and limits their access to the light. It may to secrete allelopathic substances to the soil. The aim of this study was to determine the effect of aqueous extracts from shoots G. aparine L. concentrations of 1,3, and 5\% on growth seedlings of Zea mays L. in two varieties: 'Lokata' F2, 'Wilga' F1 and F2. The seeds were placed on Petri dishes (100 units) and watered extracts from shoots G. aparine, and distilled water (control). The ability of seed germination was higher on extracts of concentration $1 \%$ for the variety 'Wilga' F1 and F2, and less for the 'Lokata' F2. Biometric analysis of seedling roots showed the stimulatory effect of $1 \%$ and $3 \%$ extracts, and the inhibitory for $5 \%$. The fresh weight of maize seedlings was significantly higher on $1 \%$ extract, as compared to other and the control. The values of the dry weight of 'Lokata' F2 each concentration was lower in comparison to the control. The water contents in seedlings of the 'Wilga' F1 and 'Lokata' F2 varieties were significantly increased of each extracts, in comparison to control.
\end{abstract}

Keywords: allelopathy, electrolyte leakage, germination, maize hybrids, morphology, seedlings

\section{Introduction}

Studies carried out so far in agrocenosis show that, both the crop plants and weeds release of chemicals substances into the environment which are toxic in high concentration, not only for other species, but also to themselves (Tanveer et al., 2012; Mahboobi and Heidarian, 2016). The weeds may adversely affect on the crop plants and it is associated not only with their competition for light, water, and mineral compounds ( $\mathrm{He}$ et al., 2011; Bullied et al., 2012; Fletcher and Reddy, 2016), but it also the fact that weeds release chemical substances into soils, which delay and inhibit the growth and development of plants, thus contribute to the overall reduction in yielding crops (Narwal, 2004; Rodrigues et al., 2014; Nalini et al., 2015; Sturm and Roland, 2016).
Sticky willy (Galium aparine L.) is a common weed, causes significant losses in yields of cereals and other crops all over the world (Fraud-Williams, 1985; Schroeder et al., 1993; Defelice, 2002; Vrbničanin et al., 2008). It is an annual plant of the Rubiaceae (bedstraw family) and is considered a cosmopolite species with a high degree of morphological and physiological plasticity. It can colonize a variety of different, natural and anthropogenic habitats. It mainly grows in cereal, rapeseed, and sugar beet crops, in garden crops, as well as on meadows, wastelands, and on roadsides (Aziz et al., 2009). It is a ruderal and nitrophilous plant. In the plant communities classification is poorly characteristic for the Galio-Urticenea SubClass (Matuszkiewicz, 2006). Its aboveground parts (leaves and stems) have hooked hairs (Gorb and Gorb, 2002; Bowling et al., 2008) and can easily wrap around other plants in order to benefit from better conditions necessary to photosynthesis 
(Goodman, 2005; Bauer et al., 2011; Hayley and Badyal, 2014). G. aparine usually produces 100 to 400 seeds with hooked hairs that facilitate the dispersion of seeds by animals (zoochory) (Moore, 2011). The vitality of seeds in soil lasts for up to three years; the seeds germinate both in shade and in full sunlight, on fertile clay soils with a $\mathrm{pH}$ value between 5.5 and 8.0 , and where the content of nitrogen and phosphorus is high (Taylor, 1999).

The aim of the study was to determine the effect of aqueous extracts of dry Galium aparine L. material (shoots) at different concentration on energy and power of germination [i], morphology (size of above- and underground parts) [ii], fresh and dry weight, percentage content of water [iii], electrolyte leakage [iv] of maize (Zea mays L.) seedlings of two varieties: 'Lokata' F2, 'Wilga' F1 and F2.

\section{Materials and Methods}

\section{Plant material}

The seeds of maize (Zea mays L.) - trilinear hybrid varieties 'Lokata' F2 (second generation) and 'Wilga' F1 and F2 (first and second generations) - were provided of the Plant Breeding Smolice Ltd. Co. IHAR Group (Poland). The sticky willy (Galium aparine L.) plant material (shoots) was collected within the protection zone of the Ojców National Park $\left(50^{\circ} 12^{\prime} 24^{\prime \prime} \mathrm{N} 19^{\circ} 49^{\prime} 45^{\prime \prime} \mathrm{E}\right.$ - South Poland) and dried at a room temperature.

\section{Preparation of extracts}

Aqueous extracts of $G$. aparine with percentage concentrations of $1,3,5 \%$ were prepared from dry shoots and crushed in a mortar. Each of the extracts were prepared in appropriate amounts of cold distilled water (i.e. as for $1 \%$ concentration rate $-99 \mathrm{ml} ; 3 \%-97 \mathrm{ml} ; 5 \%-95 \mathrm{ml}$ ) and they were left for $24 \mathrm{~h}$ at a temperature of $25^{\circ} \mathrm{C}$ in order to extract chemical compounds. The extracts were filtered by a Whatman filter in the Büchner funnel using a vacuum pump. The extracts were stored at a temperature of $7-8^{\circ} \mathrm{C}$ for one week.

\section{Germination of seeds}

The maize seeds were washed with distilled water and placed on the sterile Petri-dishes (100 seeds on every dish) with a filter papers wetted of aqueous $G$. aparine extracts at suitable concentrations. The control sample consisted of seeds placed on Petri-dishes wetted the distilled water. The seeds were put in darkness for 7 days at the temperature of $25^{\circ} \mathrm{C}$ and at $60-70 \%$ of relative humidity (RH\%). The number of germinated seeds was checked every $24 \mathrm{~h}$. In this way, energy and power of seeds germination were determined. The maize seeds with sprouts longer than one half of the seed were considered to be germinated.

\section{Biometric analysis, dry and fresh weight, percentage content of} water

After 7 days, the effects of aqueous extracts of $G$. aparine on growth of the maize seedlings were estimated, based on the length of the roots and coleoptiles, measured using an analogue calliper (Topex 31C615, Poland). A fresh weight of 7-day seedlings was determined using a laboratory scale (Medicat
$1600 \mathrm{C}$, Poland). In order to obtain a dry weight the plants material were dried in a dryer (Termaks 8430, Poland) for $48 \mathrm{~h}$ at the temperature of $105^{\circ} \mathrm{C}$. Based on the values received, a percentage content of water was determined.

\section{Electrolyte leakage}

A percentage leakage of electrolytes in maize seedlings was determined based on a method of destabilisation of cell membranes according to Sutinen et al. (1992).

\section{Statistical analysis}

The results obtained are mean values of 5 independent repetitions (100 seeds), for every concentration of the extract and control sample (distilled water). The statistical analysis was performed with the use of a non-parametric Kruskal-Wallis test, after the Levene's test for homogeneity of variances ( $p \leq$ 0.05 ). The Statistica 10.0 software for Windows was applied to perform calculations.

\section{Results}

During the first 24 hours, the number of germinated seeds two varieties of maize on the 1 and $3 \%$ allelopathic extracts, was higher compared to the control. The highest quantity of the germinated seeds of 'Lokata' F2 variety were shown. The 5\% extract of Galium aparine L. decreased the number of germinated seeds of 'Wilga' F1 and F2 variety, and increased 'Lokata' F2 variety, relative to the control. In the first $24 \mathrm{~h}$, significant differences in the number of germinated seeds were observed only between the maize seeds 'Lokata' F2 variety on distilled water, and the seeds on the extract $1 \%$. Moreover, statistical differences in the germination were reported between the seeds of the 'Wilga' $F 1$ and 'Lokata' $F 2$ varieties, placed on $1 \%$ and $5 \%$ extracts (Fig. 1).

After $48 \mathrm{~h}$, the germination energy was higher on the all $G$. aparine aqueous extracts for studied maize varieties, compared to the control sample. The only exception was the 'Wilga' F2 variety - in this case, the number of germinated seeds on the $5 \%$ extract was lower. Statistical differences in the germination of seeds in the control and those of the 'Wilga' F1 and 'Lokata' F2 varieties placed on $1 \%$ extracts were observed. For all the maize varieties studied, significant differences in the germination energy of seeds on 1 and 5\% extracts were found (Fig. 1).

After the third day, an increase in the germination of seeds of two maize varieties on the G. aparine extracts compared to control was confirmed. The exception was the 'Lokata' F2 variety, which seeds germinated in a lower amount on the 5\% extract. Significant changes in the energy of germination were observed only in the case of the 'Wilga' F1 variety, between seeds placed on $1 \%$ and $5 \%$ extracts (Fig. 1).

After 7 days, the $1 \%$ extracts of $G$. aparine stimulated germination of seeds the 'Wilga' F1 and F2 variety, and inhibited the 'Lokata' F2, compared to the control were observed. The 3\% and 5\% extracts of G. aparine inhibited the germination of both maize varieties (Fig. 1). Between the seeds of 'Wilga' F1 variety germinated on the $1 \%$ and $5 \%$ extracts, the statistically significant differences of the analysed extracts were observed. The 'Lokata' F2 variety seeds showed differences in the germination on the 5\% extract, compared to control seeds (Fig. 1). 
520

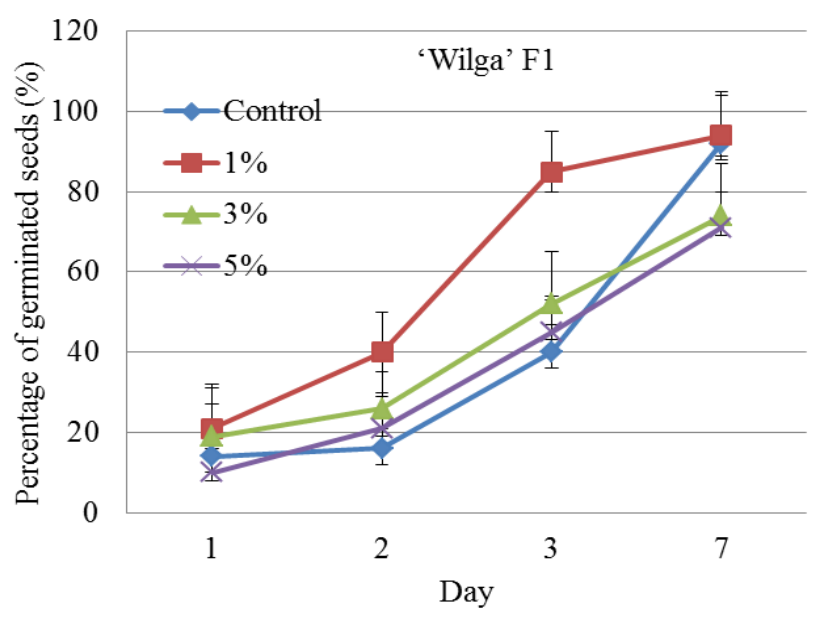

'Wilga' F2
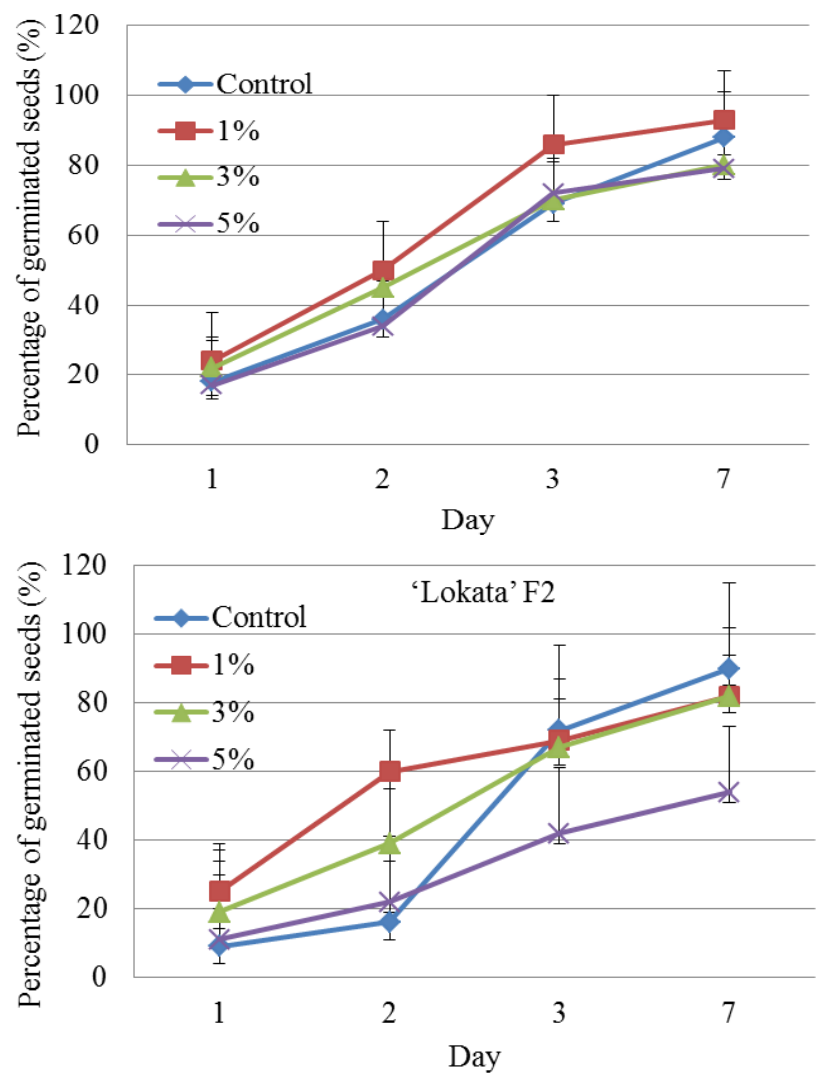

Fig. 1. Effect of aqueous extracts of dry shoots of Galium aparine L. on germination of maize seeds (Zea mays L.: 'Wilga' F1, F2, 'Lokata' F2 varieties); mean values $\pm S D, n=5$

Biometric analysis of the maize seedlings roots in both varieties showed a significant stimulatory effect of all used concentrations of $G$. aparine extracts on the growth seedlings, compared to control group. The longest roots of the maize seedlings in the 'Lokata' F2 variety on the $1 \%$ and $3 \%$ extracts were observed. The $5 \%$ aqueous extract significantly stimulated the growth of seeds 'Wilga' F2 variety (Fig. 2).

In the case of the coleoptiles of maize seedlings, the $1 \%$ extract of $G$. aparine had the most stimulating effect on the 'Wilga' F1 and the lowest on 'Lokata' F2 variety, compared to

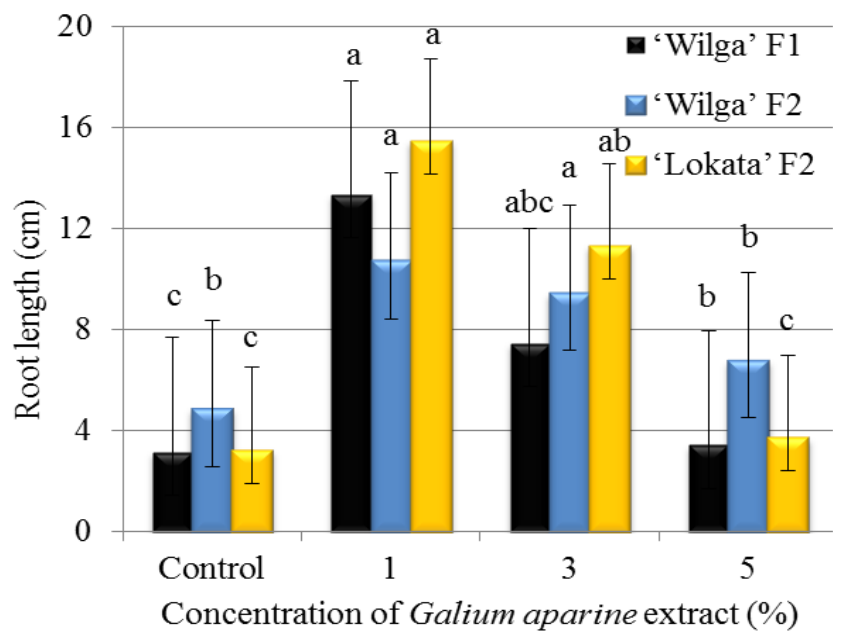

Fig. 2. Effect of aqueous extracts of dry shoots of Galium aparine $\mathrm{L}$. on length of roots of maize seedlings (Zea mays $\mathrm{L}$.: 'Wilga' F1, F2, 'Lokata' F2 varieties); mean values \pm SD n $=5$ marked by different letters differ significantly to KruskalWallis test at $\mathrm{p} \leq 0.05$

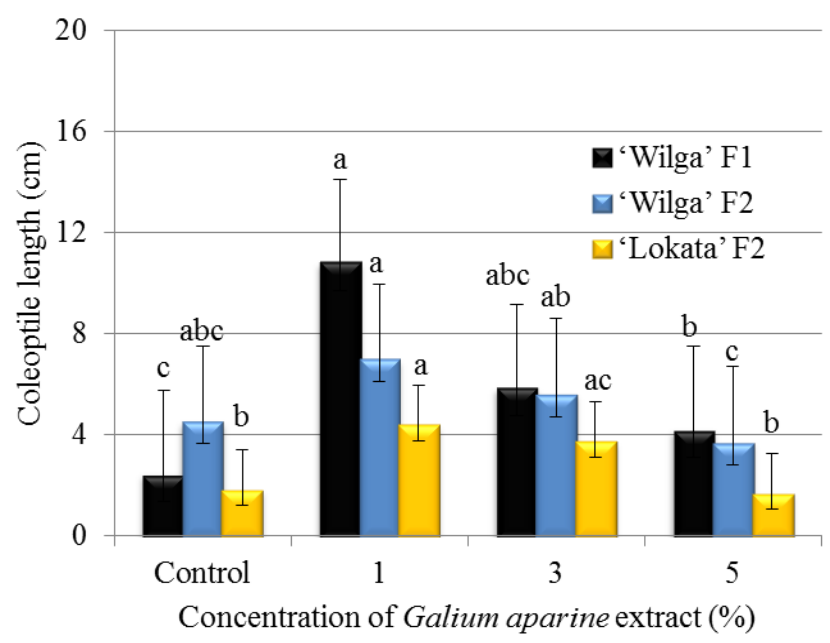

Fig. 3. Effect of aqueous extracts of dry shoots of Galium aparine $\mathrm{L}$. on length of coleoptiles of maize seedlings (Zea mays L.: 'Wilga' F1, F2, 'Lokata' F2 varieties); mean values \pm SD (n $=5$ ), marked by different letters differ significantly to KruskalWallis test at $\mathrm{p} \leq 0.05$

the control seedlings. With increasing concentration of aqueous extracts, the growth of seedlings of two varieties was significantly decreased, in comparison to the coleoptiles growth on the $1 \%$ extract of $G$. aparine. As compared to control, the $3 \%$ and $5 \%$ extracts stimulated the growth of analysed maize varieties, however, less than $1 \%$ extract (Fig. 3).

The aqueous extracts of $G$. aparine stimulated the increase of fresh weight of all the maize varieties (Table 1). The highest increase of the fresh weight of maize seedlings on the $1 \%$ extract was observed. Compared to the control, the highest values of fresh weight were observed in the 'Lokata' F2 variety, and the lowest in the 'Wilga' F2 variety. Compared to the control, the significant changes in the fresh weight of seedlings of the 'Wilga' F1 variety on 3\% and 5\% extracts were noticed. The 
significant decreased of the dry weight value of the 'Lokata' F2 variety maize seedlings were observed, compared to the control; in the case of the 'Wilga' $F 1$ and $F 2$ variety no significant effects of aqueous extracts on the changes in the increase of dry weight were found. The percentage of water content, in two maize varieties, was the highest on the $1 \%$ aqueous extracts, compared to the control. The $3 \%$ and $5 \%$ extracts, caused a statistically significant increase water content in the seedlings of 'Wilga' F1 and 'Lokata' F2 varieties (Table 1).

With increasing concentration of allelopathic substances in aqueous extracts of $G$. aparine shoots, an increase the destabilisation of cell membranes of the maize seedlings was found. Compared to the control, the highest percentage of electrolyte leakage in the maize seedlings germinated on the 5\% extract was showed; the 'Lokata' F2 variety was the most sensitive. Significant differences in the flow of electrolyte was also showed between control and the $1 \%$ extract for seedlings 'Lokata' F2 variety, and between $1 \%$ and $5 \%$ extracts for seedlings 'Wilga' F1 variety (Fig. 4).

\section{Discussion}

Occurrence of weeds depend on a biological properties, environmental factors, applied technologies, and types of crops (Mačák et al., 2008; Van der Weide et al., 2008). Among other,

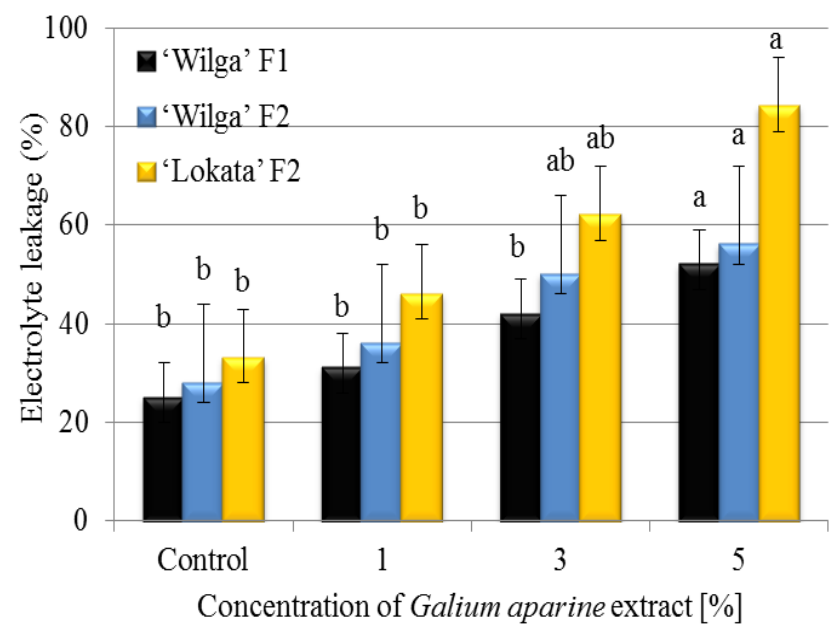

Fig. 4. Effect of aqueous extracts of dry shoots of Gallium aparine L. on electrolyte leakage from cells of maize seedlings (Zea mays L.: 'Wilga' F1, F2, 'Lokata' F2 varieties) mean values $\pm S D(n=5)$, marked by different letters differ significantly to Kruskal-Wallis test at $\mathrm{p} \leq 0.05$ a new mechanical technologies and agro-technical methods apply in agriculture facilitate the dispersion of weeds. They consist in making the ploughing shallower or in replacing it with disc harrowing, ploughless tillage works, and direct sowing (Jelonkiewicz and Borowy, 2009; Błażewicz-Woźniak and Konopiński, 2012); they also include an increased fertilization and incorporating intercrops. These techniques cause the biological diversity of agro-habitats is changed, soil processes are disturbed, and the interrelationship between fauna and flora (especially microflora) are disrupted (Kieć and Wieczorek, 2009).

At its early vegetation stages, a maize (Zea mays L.) is very susceptible to the competing effects of weeds and spraying with herbicides is indispensable for its further development. In the initial period of growth, the inter-rows between the germinating maize seeds are not covered, which facilitates rapid germination and growth of weeds. The yield of the maize crop is not only related to environmental factors, as well as the number and weight of competing weeds in the cultivation (Connolly and Wayne, 1996). Sticky willy (Galium aparine L.) is one of many prevailing weeds species to occur very often on the most intensively utilized arable lands within the temperate climate zone. In maize crops this weed is rather rare, because it is early germinating, and therefore its seedlings are effectively destroyed before sowing of a maize. A maize in the mature stage due to the large size of probably efficiently shading sticky willy, like other weeds. However, $G$. aparine is characterised by an exceptionally high morphological plasticity (Didon, 2002), it contains many chemical substances; therefore, it is not by chance that sticky willy has become the object of our study. The herb of G. aparine is dominated by fatty acids and terpenoids. Other compounds in this herb are: coumarin glycoside, coumarins and their derivatives, tannin and saponin substances (Baser et al., 2004). According to the literature, in the aqueous essential oils made from the aboveground parts of sticky willy, there are 72 chemical compounds (64.7\%). The main ingredient of the oils produced during the hydrolysis of $G$. aparine is hexadecanoic acid (22.3\%). Cai et al. (2010) state that the essential oil made from G. aparine var. tenerum (Gren. \& Godr.) Rchb. f. contains as much as 110 compounds. The major compounds are $\mathrm{n}$-hexadecanoic acid (13.88\%), linalool (11.90\%), 2-pentadecanone, 6,10,14-trimethyl (8.79\%), 1,4hexadiene, 3-ethyl- (2.37\%), furan, 2-pentyl (2.09\%), 2-hexenal (1.90\%), hexanal (1.89\%), (Z)-geraniol (1.84\%), $\alpha$-terpineol (1.83\%), and phytol (1.81\%). The sticky willy is a plant characterized by a complex chemical composition and potential allelopathic properties that may affect arable crops in different ways.

Table 1. Comparing fresh and dry weight of and percentage of water content in maize seedlings (Zea mays L.: 'Wilga' F1 - A, 'Wilga' F2 - B, and 'Lokata' F2 - C varieties) germinated on aqueous extracts of dry shoots of sticky willy (Galium aparine L.)

\begin{tabular}{|c|c|c|c|c|c|c|c|c|c|c|c|c|}
\hline \multirow{4}{*}{ Parameters } & \multicolumn{12}{|c|}{ Concentration of aqueous extract of shoots of sticky willy (Galium aparine L.) (\%) } \\
\hline & \multicolumn{3}{|c|}{ Control } & \multicolumn{3}{|c|}{1} & \multicolumn{3}{|c|}{3} & \multicolumn{3}{|c|}{5} \\
\hline & \multicolumn{12}{|c|}{ Maize variety (Zea mays L.) } \\
\hline & A & $\mathrm{B}$ & $\mathrm{C}$ & $\mathrm{A}$ & $\mathrm{B}$ & $\mathrm{C}$ & $\mathrm{A}$ & $\mathrm{B}$ & $\mathrm{C}$ & $\mathrm{A}$ & $\mathrm{B}$ & $\mathrm{C}$ \\
\hline \multirow{2}{*}{ Fresh weight $(\mathrm{g})$} & $0.44^{c}$ & $0.67^{b}$ & $0.59^{\mathrm{b}}$ & $0.98^{\mathrm{a}}$ & $0.79^{\mathrm{a}}$ & $1.18^{\mathrm{a}}$ & $0.77^{\mathrm{b}}$ & $0.72^{\mathrm{ab}}$ & $0.71^{\mathrm{b}}$ & $0.62^{b}$ & $0.63^{\mathrm{b}}$ & $0.53^{\mathrm{b}}$ \\
\hline & \pm 0.04 & \pm 0.09 & \pm 0.06 & \pm 0.21 & \pm 0.12 & \pm 0.40 & \pm 0.18 & \pm 0.09 & \pm 0.09 & \pm 0.12 & \pm 0.15 & \pm 0.06 \\
\hline \multirow{2}{*}{ Dry weight $(\mathrm{g})$} & $0.20^{\mathrm{a}}$ & $0.17^{\mathrm{a}}$ & $0.28^{\mathrm{a}}$ & $0.18^{\mathrm{a}}$ & $0.17^{\mathrm{a}}$ & $0.21^{\mathrm{b}}$ & $0.22^{\mathrm{a}}$ & $0.17^{\mathrm{a}}$ & $0.21^{\mathrm{b}}$ & $0.19^{\mathrm{a}}$ & $0.18^{\mathrm{a}}$ & $0.22^{\mathrm{b}}$ \\
\hline & \pm 0.02 & \pm 0.02 & \pm 0.06 & \pm 0.02 & \pm 0.03 & \pm 0.03 & \pm 0.03 & \pm 0.03 & \pm 0.03 & \pm 0.04 & \pm 0.05 & \pm 0.03 \\
\hline \multirow{2}{*}{$\begin{array}{l}\text { Content of water } \\
(\%)\end{array}$} & $54.09^{c}$ & $74.20^{\mathrm{ab}}$ & $51.92^{\mathrm{d}}$ & $80.40^{a}$ & $78.53^{a}$ & $81.11^{\mathrm{a}}$ & $70.66^{\mathrm{b}}$ & $75.75^{\mathrm{ab}}$ & $70.12^{b}$ & $68.40^{\mathrm{b}}$ & $68.77^{b}$ & $58.47^{c}$ \\
\hline & \pm 5.66 & \pm 4.66 & \pm 14.17 & \pm 4.66 & \pm 4.44 & \pm 4.62 & \pm 6.63 & \pm 4.38 & \pm 3.21 & \pm 3.02 & \pm 12.11 & \pm 3.77 \\
\hline
\end{tabular}

Mean values \pm SD $(n=5)$, marked by ${ }^{*}$ differ significantly according to Kruskal-Wallis test at $\mathrm{p} \leq 0.05$ 
522

Germination is the first phase of the plant ontogenesis, which are influenced by many environmental factors, among them also allelo-compounds. Ciesielska and Borkowska (2010) proved that the germination of Triticum sp. seeds is impeded in the vicinity of weeds. Similar conclusions were drawn by Polcyn (1999) in the experiment with Triticum sp. and aqueous extracts of Chenopodium album L. Duer (1996), Dzienia and Wrzesińska (2003) present a contrary view; they demonstrated that aqueous extracts of weeds do not change the germination of seeds of Triticum sp., Secale sp. and $\times$ Triticosecale. According to Piskorz (2002) aqueous extracts of the aboveground shoots, for example Elymus repens (L.) Gould, in a differentiated way impact of the seed germination and the initial growth of crop plants. Jaskulski (1999) reported that an aqueous extract of Sinapis arvensis L. significantly stimulated the initial growth of Hordeum sp.

In the experiment, the maize seeds in the first day of both varieties on $1 \%$ and $3 \%$ extract of $G$. aparine germinated numerously and the largest number of germinated seeds for the 'Lokata' F2 variety were found. After 48 hours, the germination energy of seeds was higher on all aqueous allelopathic extracts compared to the control; after 7 days of the experiment, it was found that the allelopathic $1 \%$ extracts stimulated the germination of the 'Wilga' F1 and F2 variety, but they reduced the germination of 'Lokata' F2 (Fig. 1). It follows that the germination of maize seeds on the allelopathic compounds depend on the variety, and that lower concentrations of the aqueous extracts of $G$. aparine generally positive effect on the energy and germination of seeds. Kwiecińska-Poppe et al. (2007) received similar conclusions; in their experiments the aqueous extracts of dry and fresh weight of sticky willy reduced the germination of winter wheat and spring barley seeds in direct proportion to the increase in the concentration of the extract. Higher concentration of the extracts of $G$. aparine significantly decreased the growth of the first leaf and embryonic roots of the both species, whereas the low concentrations stimulated their growth.

According to Jaskulski (1997), the occurrence of sticky willy reduces the increase in the mass of the spring barley seedlings by $23.8 \%$ and that of the spring wheat seedling by $28.7 \%$. A decreased germination of wheat in the presence of $G$. aparine was also reported by Mennan and Zandstra (2005). In the present experiment, the biometric analysis of roots and coleoptiles of the 7 day old seedlings of the two varieties demonstrated that all the concentration of the $G$. aparine extracts a significantly stimulated the growth of the seedlings, compared to the control. However, higher concentration of the extracts were supposed a lower impact on the growth of roots and coleoptiles of maize seedlings (Fig. 2,3). Similarly, the aqueous extracts stimulated the growth of fresh weight of all maize varieties; the highest increase in fresh weight was reported in the maize seedlings on the $1 \%$ extract. Only the 'Lokata' F2 variety showed a significant reduction of dry weight, but for the Wilga F1 and F2 variety non-observed impact to changes in the increase in dry weight (Table 1). This supports the conclusion that the response of maize seedlings growth to the presence of allelopatin of $G$. aparine depend on their concentration and the tolerance of different varieties. Generally, the $1 \%$ concentration of sticky willy shoots extract on majority of growth parameters of maize was stimulated.

In maize, essential oils and monoterpenes such as: menthol, camphor, geraniol, and $\alpha$-pinen, cause the increase of lipids peroxidation (Zunino and Zygadlo, 2004). Allelopathic substances cause changes at an ultra-structural level of cells, for example: enhance the vacuolation of cells, reduce the amount of mitochondria, the density of ribosomes and diktiosoms. Most probably, inhibition of cell growth of roots in the presence of allelopathic compounds result of disturbance in lipid metabolism and a reduction in protein synthesis (Baleroni et al., 2000; Burgos et al., 2004). The studies of the maize seedlings showed that the highest percentage of electrolyte leakage was in both the varieties germinated on the $5 \%$ extract - the 'Lokata' F2 variety was the most sensitive (Fig. 4). In this case, clearly negative impact of high concentrations of allelopatin from G. aparine was indicated.

Conducted studies showed that not all weeds adversely affect crops. On the contrary, some substances in the weeds have a positive impact on the processes of growth and development plants. It depends mainly on the species of cultivated plants as well as on the occurrence and density of weeds in their vicinity, and on the ecological interdependence of weed-cultivated plant (Komorowska et al. 2012). Sticky willy is a very burdensome and competitive weed. In high density on a field, it changes content of water and air conditions of the soil. It climbs up on crop plants and overshadows them, and reduces their growth and sometimes totally inhibits their development. Already in an amount of 1 to 2 units per $1 \mathrm{~m}^{2}$ can reduce crop yields up to $5 \%$ (Toth et al., 2007). However, it contains chemical substances at low concentrations which can positive impact in the initial stages of development, e.g. maize seeds; only high concentrations cause some adverse impacts, affecting the further development of $Z$. mays seedlings.

\section{Conclusions}

For the analysed Zea mays $\mathrm{L}$. varieties the most stimulating effect of $1 \%$ extract of dry shoots Galium aparine L. on germination, seedlings size and growth of their weights was found. The increase or decrease in the quantity of germinated seeds depended on the maize variety compared to the control seedlings was proved [i]. The 3\% and $5 \%$ aqueous extracts of $G$. aparine positively affected on the germination and morphology of the maize varieties, but their impact was significantly lower compared to the $1 \%$ extract. The longest seedlings for both varieties of maize on the $1 \%$ extract compared to seedlings grew on distilled water (control) was observed [ii]. Values of fresh weight were significantly higher in maize seedlings germinated on the $1 \%$ extract of $G$. aparine, compared to other extracts and the control; the percentage water content was the highest in seedlings germinated on the $1 \%$ extract for both maize varieties [iii]. The greatest electrolyte leakage in the seedlings both maize varieties on the $5 \%$ extract was observed, compared to control and lower concentration of extracts [iv].

\section{References}

Aziz A, Tanveer A, Ali A, Yaseen M (2009). Density dependent interactions between cleavers (Galium aparine) and wheat (Triticum aestivum) planted at different times. Pakistan Journal of Agricultural Science 46:258-265.

Baleroni CRS, Ferrarese MLL, Souza NE, Ferrarese-Filho O (2000). Lipid 
accumulation during canola seed germination in response to cinnamic acid derivatives. Biologia Plantarum 43(2):313-316.

Baser KHC, Özek T, Kurmer N, Deliorman D, Ergun F (2004). Composition of the Essential Oils of Galium aparine L. and Galium odoratum (L.). Scop. from Turkey. Journal of Essential Oil Research 16(4):305-307.

Bauer G, Klein MC, Gorb SN, Speck T, Voigt D, Gallenmüller F (2011). Always on the bright side: the climbing mechanism of Galium aparine. Proceedings. Biological sciences/The Royal Society 278(1715):22332239.

Błażewicz-Woźniak M, Konopiński M (2012). The influence of intercrop plants and the date of their ploughing-in on weed infestation of root chicory (Cichorium intybus L.) var. sativum (Bisch.) Janch. Acta Agrobotanica 62(1):137-146.

Bowling AJ, Maxwell HB, Vaughn KC (2008). Unusual trichome structure and composition in mericarps of catchweed bedstraw (Galium aparine). Protoplasma233(3-4):223-230.

Bullied WJ, Bullock PR, Van Acker RC (2012). Modelling soil water retention for weed seed germination sensitivity to water potential. Applied \&Environmental Soil Science pp 1-13.

Burgos NR, Talbert RE, Kim KS, Kuk YI (2004). Growth inhibition and root ultrastructure of cucumber seedlings exposed to allelochemicals from rye (Secale cereale). Journal ofChemical Ecology30(3):671-689.

Cai XM, Wang DP, YangJ (2010). Analysis of the Volatile Constituents of Galium aparine L. var. tenerum by GC-MS. Natural Product Research andDevelopment 22(6):1031-1035.

Ciesielska A, Borkowska M (2010). The effect of aqueous extracts of ground seeds of Agrostemma githago on the germination of winter wheat and barley.Journal of Research and Applications in Agricultural Engineering 55(3):40-43.

Connolly J, Wayne P (1996). Asymmetric competition between plant species. Oecologia 108:311-320.

Defelice MS (2002). Catchweed bedstraw or cleavers, Galium aparine L. - a very “sticky" subject. Weed Technology 16:467-472.

Didon UME (2002). Variation between barley cultivars in early response to weed competition. Journal of Agronomy and CropScience188:176-184.

Duer I (1996). Potencjał allelopatyczny biomasy niektórych gatunków chwastów w stosunku do siewek pszenicy ozimej (Triticum aestivum var. vulgare) [Allelopathic potential of biomass of some weed species in relation to winter wheat seedlings (Triticum aestivum var. vulgare)]. Fragmenta Agronomica 2(50):6-56.

Dzienia S, Wrzesińska E (2003). Wplyw wodnych wyciagów z wybranych gatunków chwastów na energię kiekkowania i wzrost siewek zbóż [Effects of water extracts from selected weed species on germination energy and growth of cereal seedlings]. Pamiętnik Puławski 134:79-87.

Fletcher RS, Reddy KN (2016). Random forest and leaf multispectral reflectance data to differentiate three soybean varieties from two pigweeds. Computers and Electronics in Agriculture 128:199-206.

Fraud-Williams RJ (1985). The biology of cleavers (Galium aparine). Aspects of Applied Biology 9:189-195.

Goodman AM (2005). Mechanical adaptations of cleavers (Galium aparine). Annals of Botany 95(3):475-480.
Gorb E, Gorb S (2002). Contact separation force of the fruit burrs in four plant species adapted to dispersal by mechanical interlocking. Plant Physiology and Biochemistry 40(4):373-381.

Hayley GA, Badyal JPS (2014). Bioinspired hook surfaces based upon a ubiquitous weed (Galium aparine) for dry adhesion. Journal of Adhesion Science and Technology 28(13):1243-1255.

He Y, Liu Z, Zhang J, Wang H, Shi J, Xu J (2011). Can assessing for potential contribution of soil organic and inorganic components for butachlor sorption be improved? Journal of Environmental Quality 40(6):1705-1713.

Jaskulski D (1997). Przejawy oddziaływań allelopatycznych w agrofitocenozach [Manifestations of allelopathic effects in agrophytocenoses]. Postępy Nauk Rolniczych 4:3-13.

Jaskulski D (1999). Allelopatyczne oddziaływanie wodnych ekstraktów z nadziemnej masy chwastów na kietkowanie jęczmienia jarego i pszenicy jarej [Allelopathic effect of water extracts of aboveground mass of weeds on germinating of spring barley and spring wheat]. Zeszyty Naukowe Akademii Techniczno-Rolniczej w Bydgoszczy, Rolnictwo 43(217):715.

Jelonkiewicz M, Borowy A (2009). Growth and yield of cucumber under no-tillage cultivation using rye as a cover crop. Acta Agrobotanica 62(1):147-153.

Kieć J, Wieczorek D (2009). Badania nad przydatnością wyciagów i wywarów roślinnych do zwalczania komosy białej [The research on the usefulness of plant extracts and decoctions to fight the white goosefoot]. Progress in Plant Protection/Postępy w Ochronie Roślin 49(1):371377.

Komorowska A, Wrzesińska E, Bochyński P (2012). Allelopathic potential of water extracts from weeds towards plovers of the winter wheat and the rye. Folia Pomeraniae Universitatis Technologiae Stetinensis, Agricultura, Alimentaria Piscaria etZootechnica296(23):43-52.

Kwiecińska-Poppe E, Kraska P, Pałys E (2007). Germination energy and capacity of Triticum aestivum and Hordeum vulgare depending on the allelopathic potential of water extracts from Galium aparine. Annales Universitatis Mariae Curie-Skłodowska, SectioE62(2):168-176.

Macák M, Žák Š, Djalovic I, Szombathová N (2008). The influence of an ecological and low input systems on weed density, weed diversity and weed competition on spring barley. Journal of Plant Diseases and Protenction 21:425-430.

Mahboobi N, Heidarian AR (2016). Allelopathic effects of medicinal plants on germination and seedling growth of some weeds. Journal of Fundamental \& Applied Sciences 8:323-336.

Malik N, Vanden Born WH (1988). The biology of Canadian weeds. 86. Galium aparine L. and Galium spurium L. Canadian Journal of Plant Science 68(2):481-499.

MatuszkiewiczW (2006). Przewodnik do oznaczaniazbiorowisk roślinnych Polski [Guide for the determination of Polish plant communities]. Wydawnictwo NaukowePWN, Warszawa.

Mennan S, Zandstra BH (2005). Effect of wheat (Triticum aestivum) cultivars and seeding rate on yield loss from Galium aparine (cleavers). Crop Protection 24(12):1061-1067.

Moore RJ (2011). The Galium aparine complex in Canada. Canadian Journal of Botany 53(9):877-893. 
524

Nalini K, Murhukrishnan P, Chinnusamy C, Vennila C (2015). Weeds of cotton - A Review. Agricultural Research Communication Centre 36(2):140-146.

Narwal SS (2004) Allelopathy in crop production. Scientific Publishers, Jodhapur,Indiapp. 326-332.

Piskorz B (2002). Oddziaływanie wodnych wyciagów z roślin perzu właściwego (Agropyron repens L.) na kiekkowanie i początkowy wzrost wybranych roślin uprawnych. Cz. I. Wyciagi pędów nadziemnych [The impact of aqueous plant extracts from proper couch grass (Agropyron repens $\mathrm{L}$.) on germination and initial growth of selected plant crops. Part I. Extracts from shoots above ground]. Rocznik Nauk Rolniczych Seria A 116:1-4,27-38.

Polcyn J (1999). Potencjał allelopatyczny wyciagu wodnego z części nadziemnej komosy białej w stosunku do siewek pszenicy jarej 'Igna' [Allelopathic potential of the water extract of Chenopodium album in relation to spring wheat seedlings 'Igna']. Zeszyty Naukowe Akademii Techniczno-Rolniczejw Bydgoszczy, Rolnictwo 43(217):25-29.

Rodrigues OL, GalvãoJCC, Ferreira EA, Silva DV, Santos MV, Ferreira LR, Pereira RC, Felipe RS (2014). Physiologic characteristics of corn and Urochloa brizantha (Hochst. ex A. Rich.) RD. Webster in intercropping cultivation. Chilean Journal of Agricultural Research 74(3):257-262.

Royo-Esnal A, Torra J, Conesa JA, Recasens J (2012). Emergence and early growth of Galium aparine and Galium spurium. Weed Research 52:458-466.

Schroeder D, Müller-Schaerer S, Stinson CSA 1993. A European weed survey in 10 major crop system to identify targets for biological control. Weed Research 33(6):449-458.
Sturm DJ, Roland G (2016). Comparison of different cover crop mulches and extracts on inhibition of crop and weed growth. Julius-KühnArchiv 452:424430.

Sutinen ML, Palta JP, Reich PB (1992). Seasonal differences in freezing stress resistance of needles of Pinus nigra and Pinus resinosa: evaluation of the electrolyteleakage method. Tree Physiology 11:241-254.

Tanveer AJ, Muhammad K, Kahliq A, Matloob A, Abbas RN, Javaid MM (2012). Allelopathic effects of aqueous and organic fractions of Euphorbia dracunculoides Lam. On germination and seedling growth of chickpea and wheat. Chilean Journal of Agricultural Research 72(4):495-501.

Taylor K (1999). Galium aparine L. Journal ofEcology 87(4):713-730.

Toth L, Reisinger P, Pali O (2007). The harmful effect of cleavers (Galium aparine) in winter wheat. Magyar Gyomkutatas es Technologia 8:49-57.

Van der Weide RY, Bleeker PO, Achten VTJM, Lotz LAP, Fogelberg F, Melander B (2008). Innovation in mechanical weed control in crop rows. Weed Research 48:215-224.

Vrbničanin S, Kresović M, Božić D, Simić A, Živković N (2008). The effect of crop density and applied nitrogen on the interaction between Lolium italicum and Galium aparine. Journal of Agricultural Science 53:125143.

Zunino MP, ZygadloJA (2004). Effect of monoterpenes on lipid oxidation in maize. Planta219:303-309. 